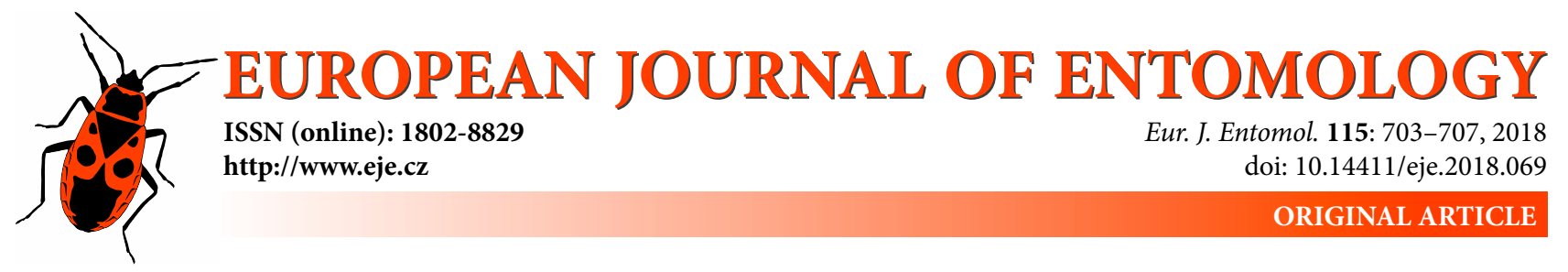

\title{
Effect of aphid abundance and urbanization on the abundance of Harmonia axyridis (Coleoptera: Coccinellidae)
}

\author{
ALOIS HONĚK, ZdenKa MARTINKOVÁ and JAN ŠTROBACH \\ Crop Research Institute, Drnovska 507, CZ-16106 Praha 6 - Ruzyně, Czech Republic; e-mails: honek@vurv.cz, \\ martinkova@vurv.cz, strobach@vurv.cz
}

\begin{abstract}
Key words. Aphididae, Eucallipterus tiliae, Coleoptera, Coccinellidae, Harmonia axyridis, Tilia, tree, abundance, distribution, population, urbanization
\end{abstract}

\begin{abstract}
The factors that affect the local distribution of the invasive Harmonia axyridis are not yet completely resolved. Hypotheses predicting positive and independent effects of prey abundance and degree of urbanization on the adult abundance of this species in Central Europe were tested. Populations of $H$. axyridis were sampled in a period when it was most abundant, by sweeping lime trees (Tilia spp.) at 28 sites along a $20 \mathrm{~km}$ transect across urban (western Prague) and surrounding rural areas. The sites differed in aphid abundance (number of Eucallipterus tiliae per 100 sweeps) and degree of urbanization (percentage of the surrounding area within a $500 \mathrm{~m}$ radius covered by impervious human constructions). Multiple linear regression analysis of log-transformed data revealed that abundance of $H$. axyridis (number of adults per 100 sweeps) increased significantly with both aphid abundance $(P=0.015)$ and urbanization $(P=0.045)$. The positive relationship between degree of urbanization and abundance of $H$. axyridis was thus not a side effect of variation in aphid abundance, which was also greater in urban than rural areas. The effect of urbanization might constrict the habitat available to $H$. axyridis and force this species to aggregate in urban green "refugia". These results point to a plurality of factors that determine coccinellid abundance at natural sites.
\end{abstract}

\section{INTRODUCTION}

Harmonia axyridis (Pallas), an aphidophagous lady beetle species native to the eastern Palearctic, Japan, China, Mongolia and Russian Siberia east of the Urals (Kovar, 2007; Bidinger et al., 2012), is worthy of attention because of its recent spread across the rest of world except Australia and New Zealand (Brown et al., 2011). The history, causes and consequences of this invasion are well investigated and authoritatively reviewed by Roy et al. (2016).

Great attention is paid to the factors affecting the distribution of $H$. axyridis in invaded areas (Bidinger et al., 2012). In Europe, this species gradually spread east and west from France, Belgium and Great Britain, where it first became established in the early 2000s (Adriaens et al., 2008). The spread was rapid in a longitudinal direction resulting in $H$. axyridis arriving in central and southern Russia in the 2010s (Korotayev, 2013; Ukrainsky \& Orlova-Bienkowskaja, 2014; Zakharov, 2015) but less rapid in a latitudinal direction (Brown et al., 2008; Honek et al., 2017; Soares et al., 2017) resulting in this species arriving later in Greece (Ceryngier \& Romanowski, 2017) and Bulgaria (Tomov et al., 2009). It seems that $H$. axyridis, despite optimistic predictions (Poutsma et al., 2008), is possibly kept from colonizing dry subtropical Mediterranean areas because in these areas its life cycle is not synchronized with that of its potential prey (Honek et al., 2017).

The pattern of the local distribution of $H$. axyridis in invaded areas is also interesting. It is determined by several factors, the most important of which is its preference for particular plants. In contrast to in its native and some of the areas it has invaded, where $H$. axyridis is abundant in low-growing vegetation (Grez et al., 2014; Lu et al., 2015), in the western Palearctic it prefers trees and rarely occurs in stands of wild herbaceous plants and crops unless they are heavily infested with aphids (Adriaens et al., 2008). Harmonia axyridis aggregates at sites where aphids are abundant (Jovicic et al., 2016; Soares et al., 2017; Viglasova et al., 2017) as an abundance of food is a prerequisite for reproduction (Ovchinnikova et al., 2016) and the adults are capable of locating and populating such sites (Osawa, 2000; With et al., 2002).

Another factor affecting the distribution of $H$. axyridis is its affinity for urban areas, in Europe (Adriaens et al., 2008), North America (Colares et al., 2015), South America (Wagner et al., 2017) and South Africa (Mukwevho et al., 2017). In this tendency, $H$. axyridis is not exceptional as urban habitats are also preferred by other species of coccinellids (Gardiner et al., 2014; Latibari et al., 2016). However, the abundance of aphids (Philpott \& Bichier, 2017) 


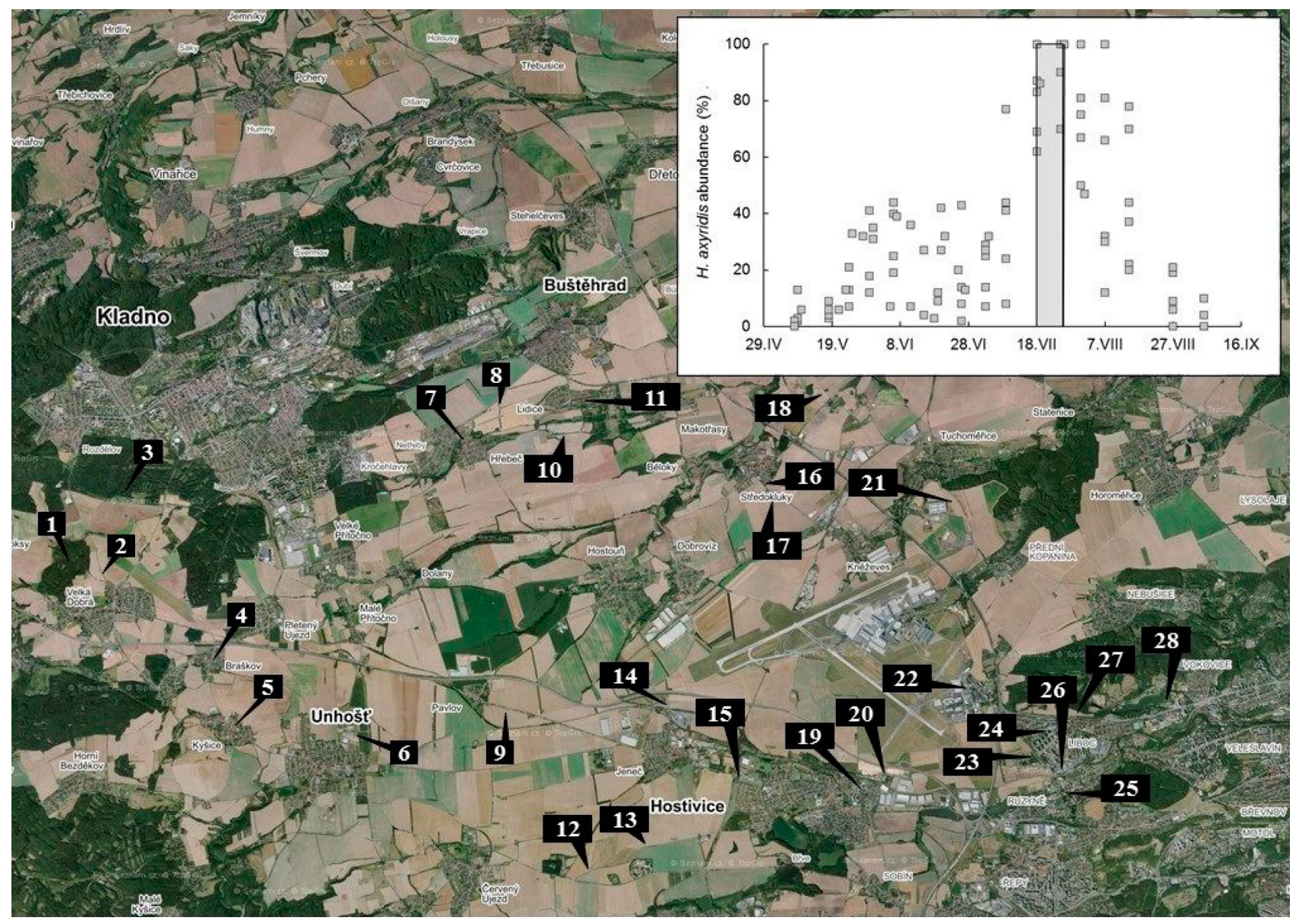

Fig. 1. Map showing the sites where the populations of $H$. axyridis were sampled. The size of the pictured area is $23 \times 16 \mathrm{~km}$ and centred at $50.134^{\circ} \mathrm{N}, 14.207^{\circ} \mathrm{E}$. Insert: Standardized abundances (percentage of maximum at each site) of $H$. axyridis recorded at sites 19,20 , 22, 23, 24 and 28 in the vegetative season in 2018. Shaded area - period when the sampling occurred.

and other sucking Hemiptera (Hanks \& Denno, 1993) is also higher in urban areas. The positive correlation between the above two factors, prey abundance and urbanization, complicates and confounds an analysis of the factors determining the abundance of $H$. axyridis.

In order to resolve this problem, the relationships between the abundance of $H$. axyridis, abundance of aphids and degree of urbanization, was studied using a standardized protocol that minimizes the confounding effects of temporal (Honek et al., 2015) and regional (Viglasova et al., 2017) differences in the abundance of $H$. axyridis. This study focused on adults that were sampled over a short period and on a single host-plant/aphid system. We tested three hypotheses: The abundance of $H$. axyridis increases (i) with aphid abundance and (ii) with the degree of urbanization (iii), and that these increases are independent of one another. The aim was to elucidate the relationship between both of the factors that are associated with the abundance of this coccinellid.

\section{MATERIAL AND METHODS}

\section{Sites sampled}

Abundance of $H$. axyridis was recorded at 28 sites scattered along an $\sim 20 \mathrm{~km}$ long longitudinal transect that extended from the west Prague into the surrounding area (Fig. 1). The tree stands at particular sites consisted of $\geq 5$ lime trees (Tilia cordata Mill., Tilia platyphyllos Scop.) infested with the aphid Eucallipterus tiliae (L.) (Sternorrhyncha: Aphididae). Continuous monitoring of coccinellid abundance on trees (Honek et al., 2018) revealed that Tilia spp. were the most infested trees at that time. There were very few ladybirds on the other species of trees growing in the urban and rural areas (Acer spp., Betula spp., Quercus spp.).

\section{Sampling period}

The lime trees were sampled in one week 18 to 24 July 2018, which was when $H$. axyridis was most abundant on the lime trees. This is confirmed by the results of a season-long monitoring of H. axyridis abundance at sites 19, 20, 22, 23, 24 and 28 (Fig. 1), during which the abundance of $\mathrm{H}$. axyridis was monitored at weekly intervals. This revealed that sampling occurred when the abundance of adult $H$. axyridis was at a maximum. One-way ANOVA using abundance of $H$. axyridis at particular sites from 15-31 July (abundance at the date included in this study and one week before and one week after, i.e., 3 records for each site, total $\mathrm{n}=18$ ) as the response variable and site as factor revealed that in this period, differences between sites accounted for $95.1 \%$ of the variance in $H$. axyridis abundance.

\section{Sampling method}

Beetles were swept from the canopy up to a height of cca $3 \mathrm{~m}$. Sampling was standardised by using a standard sweep net $(35 \mathrm{~cm}$ diameter, $140 \mathrm{~cm}$ handle) operated by the same person (A.H.). All the days on which samples were collected were sunny and calm, 
and maximum temperatures (experienced in the afternoon) were between 27.7 and $32.1^{\circ} \mathrm{C}$. Sampling occurred between 08.00 and $18.00 \mathrm{~h}$ and consisted of 100 sweeps at each site. In each sampling session, we recorded (i) abundance of $H$. axyridis (number of adults caught per 100 sweeps), (ii) abundance of aphids (approximate number of aphids caught per 100 sweeps, pilot observations revealed that aphid numbers were determined with $\sim 10 \%$ precision), and urbanization quantified as (iii) the percentage of the surrounding area (a circle of $500 \mathrm{~m}$ radius centred at the sampling site) covered by impervious surfaces (buildings, streets, parking places, etc.). The latter value was called "degree of urbanization". It was determined using maps available at (https:// en.mapy.cz).

\section{Data analysis}

The relationships between the abundance of $H$. axyridis, abundance of aphids and degree of urbanization were obtained using raw data and linear regression, $\mathrm{y}=\mathrm{a}+\mathrm{bx}$, in which $\mathrm{y}$ is the abundance of $H$. axyridis and $\mathrm{x}$ either aphid abundance or degree of urbanization. The relationship between the abundance of aphids and degree of urbanization was tested using the same formula where $y$ is the abundance of aphids and $x$ the degree of urbanization. To linearize the relationship between data variables (abundance of aphids, degree of urbanization and abundance of $H$. axyridis), the data were $\log$ transformed. Using log-transformed data, we used multiple linear regression, $\log (\mathrm{y}+1)=\mathrm{a}+\mathrm{b}_{1} \log \left(\mathrm{x}_{1}\right.$ $+1)+\mathrm{b}_{2} \log \left(\mathrm{x}_{2}+1\right)$, in which $\mathrm{y}$ is the abundance of $H$. axyridis, $\mathrm{x}_{1}$ abundance of aphids and $\mathrm{x}_{2}$ degree of urbanization. We then tested the significance of the regression coefficients $b_{1}$ and $b_{2}$ in order to determine the effect of abundance of aphids and degree of urbanization on $H$. axyridis abundance. Calculations were performed using SigmaStat 3.5 (Systat Software Inc., 2006).

\section{RESULTS}

Abundance of E. tiliae ( 0 to 820 individuals per 100 sweeps) and degree of urbanization ( 2 to 59 percent of surrounding area impervious) varied greatly among sites. Variability in the abundance of $H$. axyridis, which made up $86 \%$ of all the coccinellids sampled, was related to both factors (Fig. 2). The abundance of $H$. axyridis significantly $\left(\mathrm{F}_{1,27}=27.022, \mathrm{P}<0.001\right)$ increased with increase in the abundance aphids $\left(\mathrm{a}=14.706, \mathrm{~b}=0.0848, \mathrm{R}^{2}=0.510\right)$ and $(\mathrm{F} 1,27=18.968, \mathrm{P}<0.001)$ with increase in the degree of urbanization $\left(\mathrm{a}=11.176, \mathrm{~b}=0.986, \mathrm{R}^{2}=0.422\right)$. However, the abundance of aphids also significantly $\left(\mathrm{F}_{1,27}=28.996\right.$, $\mathrm{P}<0.001)$ increased with the degree of urbanization $(\mathrm{a}=$ $\left.11.339, \mathrm{~b}=9.276, \mathrm{R}^{2}=0.527\right)$.

Multiple regression using log transformed data $(\mathrm{a}=$ $\left.-0.194, \mathrm{~b}_{1}=0.445, \mathrm{~b}_{2}=0.484, \mathrm{R}^{2}=0.599\right)$ revealed a highly significant effect of both factors $\left(\mathrm{F}_{2,27}=18.706, \mathrm{P}<0.001\right)$. Partial regressions revealed a significant effect of both the abundance of aphids $(\mathrm{P}=0.015)$ and urbanization $(\mathrm{P}=$ $0.047)$ on $H$. axyridis abundance.

\section{DISCUSSION}

The results revealed a positive effect of the abundance of aphids on the abundance of adults of $H$. axyridis, which is consistent with the prediction of hypothesis (i). This result is expected and consistent with earlier evidence (Hodek \& Evans, 2012; Honek, 2012). While there is no doubt that the abundance of aphids has an important role in determin-
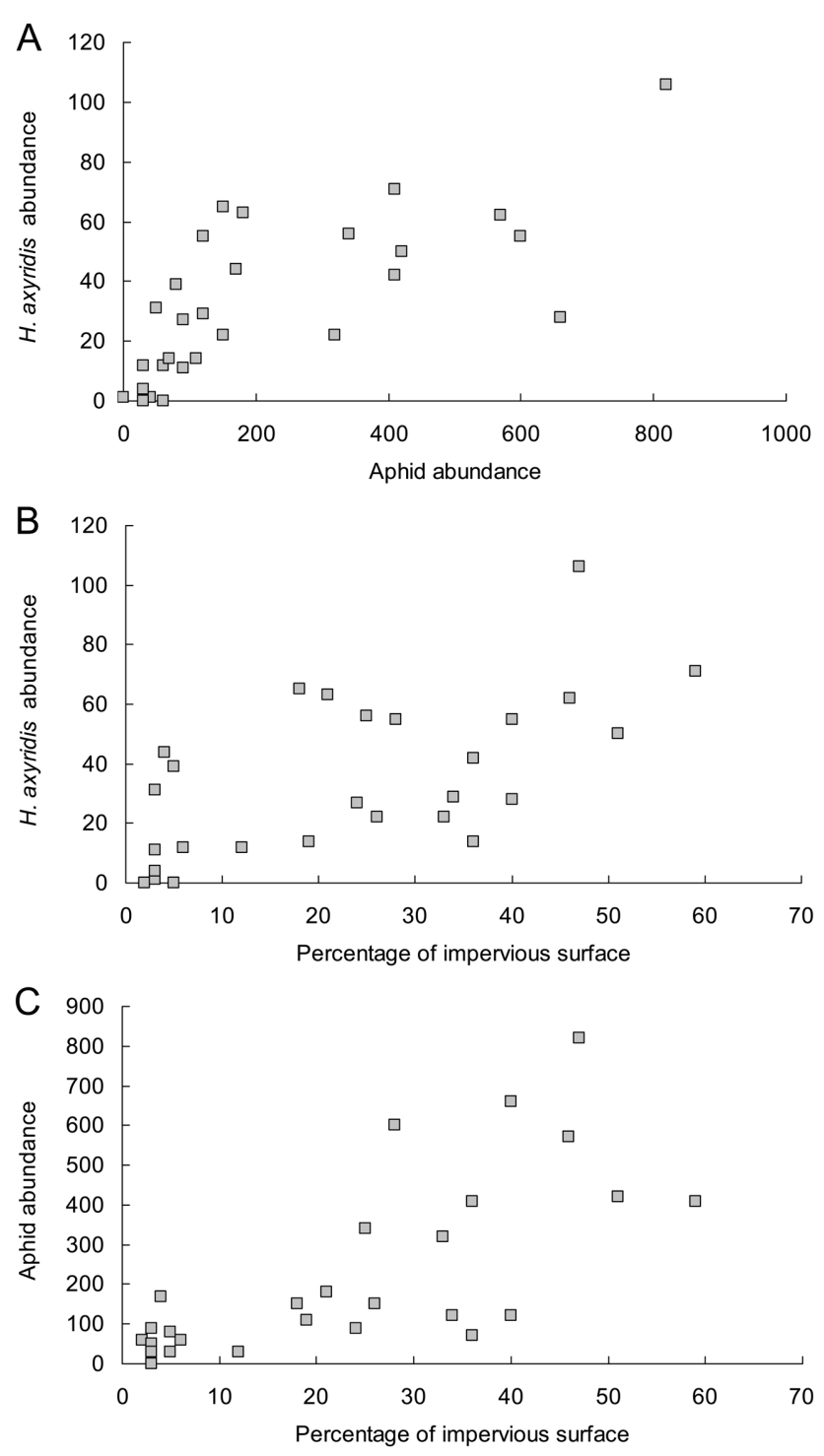

Fig. 2. The relationship between the abundance of Harmonia axyridis ( $\mathrm{n}$ individuals per 100 sweeps) and $\mathrm{A}-$ the abundance of aphids (n Eucallipterus tiliae individuals per 100 sweeps), B - the degree of urbanization, and $C$ the interrelationship between abundance of aphids and degree of urbanization.

ing the abundance of many coccinellids, identification of the relative importance of the population processes that determine the maximum abundance of $H$. axyridis at a particular site needs further study. Adult populations consist of individuals arriving from the surrounding area as well as individuals that developed at the site. Population size is thus determined by a combined effect of the settling of adult immigrants at a site (Osawa, 2000; With et al., 2002), intensity of oviposition (Osawa, 2005; Seagraves, 2009) and success of pre-imaginal development (Hironori \& Katsuhiro, 1997), which are all positively affected by aphid abundance.

The results further reveal a weaker but significant positive effect of urbanization, consistent with hypothesis (ii). The positive effect of the urban environment on the abundance of $H$. axyridis (Adriaens et al., 2008; Mukwevho et al., 2017; Wagner et al., 2017) and its role in facilitating 
the rapid spread of this species (Veran et al., 2016) are well documented, but contrary effects are also reported (Rocha $\&$ Fellowes, 2018; Rocha et al., 2018). The mechanism behind the effect of urbanization is not yet resolved (Honek et al., 2017; Sloggett, 2017). We hypothesize that in rural areas, coccinellids may be distributed evenly, while in cities, where the suitable habitat is reduced to small patches of green (parks, green courtyards, tree lines bordering streets), coccinellids are forced to aggregate at these sites. Urban greens thus serve as small refugia in an otherwise hostile urban environment.

The positive effect of urbanization on $H$. axyridis abundance may be confounded by its parallel effect on aphid abundance. A positive relation between aphid abundance and urban environment has been established several times (Fluckiger \& Braun, 1999; Mackos-Iwaszko et al., 2015), although contrary cases describing lower aphid abundance in urban areas compared to rural area are also reported (Sienkiewicz-Paderewska et al., 2017). In this study, a significant positive relationship was found between degree of urbanization and abundance of E. tiliae. Mechanisms underlying the effect of urbanization on aphid abundance include biotic (natural enemies) and abiotic (salinity and drought) factors (Sienkiewicz-Paderewska et al., 2017; Andrade et al., 2017; Rocha \& Fellowes, 2018). These effects, while outside the scope of this study, deserve more investigation.

Our study thus established and quantified the separate action of two factors on the abundance of $H$. axyridis, abundance of aphids and urbanization, both of which affected the abundance of $H$. axyridis independently of one another. This result is consistent with the prediction of hypothesis (iii). Both factors contribute to the local diversification of the abundance of $H$. axyridis and point to a plurality of factors that determine coccinellid abundance at natural sites.

ACKNOWLEDGEMENTS. We thank H. Uhlírová and J. Kohoutová for excellent technical assistance. $\mathrm{AH}$ and $\mathrm{ZM}$ were supported by grant no. 17-06736S of the Czech Science Agency, and all authors were supported by institutional support no. RO0418 of The Ministry of Agriculture of the Czech Republic.

\section{REFERENCES}

Adriaens T., San Martin y Gomez G. \& Maes D. 2008: Invasion history, habitat preferences and phenology of the invasive ladybird Harmonia axyridis in Belgium. - BioControl 53: 69-88.

Andrade R., Bateman H.L. \& Kang Y. 2017: Seasonality and land cover characteristics drive aphid dynamics in an arid city. - J. Arid. Environ. 144: 12-20.

Bidinger K., Lötters S., Rödder D. \& Veith M. 2012: Species distribution models for the alien invasive Asian Harlequin ladybird (Harmonia axyridis). — J. Appl. Entomol. 136: 109-123.

Brown P.M.J., Adriaens T., Bathon H., Cuppen J., Goldarazena A., Hägg T., Kenis M., Klausnitzer B.E.M., Kovar I., Loomans A.J.M. ET AL. 2008: Harmonia axyridis in Europe: spread and distribution of a non-native coccinellid. - BioControl 53: 5-21.

Brown P.M.J., Thomas C.E., Lombaert E., JefFries D.L., Estoup A. \& Lawson HandLey L.J. 2011: The global spread of Harmonia axyridis (Coleoptera: Coccinellidae): distribution, dispersal and routes of invasion. - BioControl 56: 623-641.
Ceryngier P. \& Romanowski J. 2017: Harmonia axyridis (Pallas, 1773) (Coleoptera: Coccinellidae) and its parasite in southwestern Bulgaria and northern Greece. - Bioinvasions Rec. 6: $307-310$.

Colares F., Michaud J.P., Bain C.L. \& Torres J.B. 2015: Recruitment of aphidophagous arthropods to sorghum plants infested with Melanaphis sacchari and Schizaphis graminum (Hemiptera: Aphididae). — Biol. Contr. 90: 16-24.

FLUCKIGER W. \& BRAUN S. 1999: Stress factors of urban trees and their relevance for vigour and predisposition for parasite attacks. In Lemattre M., Lemattre P. \& Lemaire F. (eds): Proceeding of the International Symposium on Urban Tree Health, Paris, France, September 22, 1997. - Acta Horticulturae 496: $325-334$.

Gardiner M.M., Prajzner S.P., Burkman C.E., Albro S. \& GreWAL P.S. 2014: Vacant land conversion to community gardens: influences on generalist arthropod predators and biocontrol services in urban greenspaces. - Urban Ecosyst. 17: 101-122.

Grez A.A., Zaviezo T., Hernandez J., Rodriguez-San Pedro A. \& ACUNA P. 2014: The heterogeneity and composition of agricultural landscapes influence native and exotic coccinellids in alfalfa fields. — Agr. Forest Entomol. 16: 382-390.

HANKs L.M. \& DENNO R.F. 1993: Natural enemies and plant water relations influence the distribution of armored scale insect. Ecology 74: 1081-1091.

Hironori Y. \& Katsuhiro S. 1997: Cannibalism and interspecific predation in two predatory ladybirds in relation to prey abundance in the field. - Entomophaga 42: 153-163.

HodeK I. \& Evans E.W. 2012: Food relationships. In Hodek I., van Emden H.F. \& Honek A. (eds): Ecology and Behaviour of the Ladybird Beetles (Coccinellidae). Wiley-Blackwell, Chichester, pp. 141-274.

HoneK A. 2012: Distribution and habitats. In Hodek I., van Emden H.F. \& Honek A. (eds): Ecology and Behaviour of the Ladybird Beetles (Coccinellidae). Wiley-Blackwell, Chichester, pp. 110-139.

Honek A., Martinkova Z. \& Dixon A.F.G. 2015: Detecting seasonal variation in composition of adult Coccinellidae communities. - Ecol. Entomol. 40: 543-552.

HoneK A., Dixon A.F.G., Soares A.O., Skuhrovec J. \& MartinkOVA Z. 2017: Spatial and temporal changes in the abundance and composition of ladybird (Coleoptera: Coccinellidae) communities. - Curr. Opin. Insect Sci. 14: 61-67.

Honek A., Martinkova Z., Roy H.E., Dixon A.F.G., Skuhrovec J., PekÁr S. \& Brabec M. 2018: Differences in the phenology of Harmonia axyridis (Coleoptera: Coccinellidae) and native coccinellids in Central Europe. — Environ. Entomol. [in press] doi: $10.1093 /$ ee/nvy173.

Jovicic I., Radonjic A. \& Petrovic-Obradovic O. 2016: Aphids (Hemiptera: Aphididae) on alfalfa and their coccinellid predators in Serbia: seasonal abundance. - Acta Zool. Bulg. 68: 581-587.

Korotayev B.A. 2013: On high abundance of the harlequin lady beetle Harmonia axyridis (Pall.) (Coleoptera, Coccinellidae) in the plains of the north western Caucasus, Russia. — Entomol. Rev. 92: 856-858.

Kovar I. 2007: Coccinellidae. In Löbl I. \& Smetana A. (eds): Catalogue of Palaearctic Coleoptera. Vol. 4. Apollo Books, Stenstrup, pp. 568-631.

Latibari M.H., Moravvej G., Namaghi H.S. \& Khormizi M.Z. 2016: Coccinellid biodiversity on the coniferous trees Thuja orientalis and Pinus mugo in urban landscape of Mashhad, Razavi Khorasan Province, Iran. - Egypt. J. Biol. Pest Contr. 26: 419-421. 
Lu Z.B., Shi P.J., Reddy G.V.P., Li L.M., Men X.Y. \& Ge F. 2015: Nonparametric estimation of interspecific spatio-temporal niche separation between two lady beetles (Coleoptera: Coccinellidae) in Bt cotton fields. - Ann. Entomol. Soc. Am. 108: 807-813.

Mackos-Iwaszko E., Lubiarz M. \& Karczmarz K. 2015: The impact of urban conditions on the occurrence of aphids on Acer platanoides L. - Acta Sci. Polon. Hort. Cult. 14: 189-207.

Mukwevho V.O., Pryke J.S. \& Roets F. 2017: Habitat preferences of the invasive harlequin ladybeetle Harmonia axyridis (Coleoptera: Coccinellidae) in the western Cape Province, South Africa. - Afr. Entomol. 25: 86-97.

Osawa N. 2000: Population field studies on the aphidophagous ladybird beetle Harmonia axyridis (Coleoptera: Coccinellidae): resource tracking and population characteristics. - Popul. Ecol. 42: 115-127.

Osawa N. 2005: The effect of prey availability on ovarian development and oosorption in the ladybird beetle Harmonia axyridis (Coleoptera: Coccinellidae). — Eur. J. Entomol. 102: 503-511.

OsaWA N. 2011: Ecology of Harmonia axyridis in natural habitats within its native range. - BioControl 56: 613-621.

Ovchinnikova A.A., Ovchinnikov A.N., Dolgovskaya M.Y.U., RezNIK S.YA. \& BeLYaKova N.A. 2016: Trophic induction of diapause in native and invasive populations of Harmonia axyridis (Coleoptera: Coccinellidae). — Eur. J. Entomol. 113: 469-475.

Philpott S.M. \& Bichier P. 2017: Local and landscape drivers of predation services in urban gardens. - Ecol. Appl. 27: 966976.

Poutsma J., Loomans A.J.M., Aukema B. \& Heijerman T. 2008: Predicting the potential geographical distribution of the harlequin ladybird, Harmonia axyridis, using the CLIMEX model. - BioControl 53: 103-125.

Rocha E.A. \& Fellowes M.D.E. 2018: Does urbanization explain differences in interactions between an insect herbivore and its natural enemies and mutualists? - Urban Ecosyst. 21: 405-417.

Rocha E.A., Souza E.N.F., Bleakley L.A.D., Burley C., Mott J.L., Rue-Glutting G. \& Fellowes M.D.E. 2018: Influence of urbanisation and plants on the diversity and abundance of aphids and their ladybird and hoverfly predators in domestic gardens. - Eur. J. Entomol 115: 140-149.

Roy H.E., Brown P.M.J., Adriaens T., Berkvens N., Borges I., Clusella Trullas S., Comont R., De Clerce P., Eschen R., Estoup A. ET AL. 2016: The harlequin ladybird, Harmonia axy- ridis: global perspectives on invasion history and ecology. Biol. Invas. 18: 997-1044.

Seagraves M.P. 2009: Lady beetle oviposition behavior in response to the trophic environment. - Biol. Contr. 51: 313-322.

Sienkiewicz-Paderewska D., Dmuchowski W., Baczewska A.H., BragoszewsKa P. \& Gozdowski D. 2017: The effect of salt stress on lime aphid abundance on Crimean linden (Tilia 'Euchlora') leaves. - Urban For. Urban Green. 21: 74-79.

SloggetT J.J. 2017: Harmonia axyridis (Coleoptera: Coccinellidae): smelling the rat in native ladybird declines. - Eur. $J$. Entomol. 114: 455-461.

Soares A.O., Honek A., Martinkova Z., Skuhrovec J., Cardoso P. \& Borges I. 2017: Harmonia axyridis did not establish in the Azores: the role of species richness, intraguild interactions and resource availability. - BioControl 62: 423-434.

Systat Software Inc. 2006: SigmaStat 3.5. Systat Software Inc. Point Richmond, CA

Tomov R., Trencheva K., Trenchev G. \& Kenis M. 2009: The Multicolored invasive Asian ladybird Harmonia axyridis (Pallas, 1773) (Coleoptera: Coccinellidae) new to the fauna of Bulgaria. - Acta Zool. Bulgar. 61: 307-311.

UkRainsky A.S. \& Orlova-Bienkowskaja M.J. 2014: Expansion of Harmonia axyridis Pallas (Coleoptera: Coccinellidae) to European Russia and adjacent regions. - Biol. Invas. 16: 1003-1008.

Veran S., Piry S., Ternois V., Meynard C.N., Facon B. \& Estoup A. 2016: Modeling spatial expansion of invasive alien species: relative contributions of environmental and anthropogenic factors to the spreading of the harlequin ladybird in France. Ecography 39: 665-675.

Viglasova S., Nedved O., Zach P., Kulfan J., Parak M., Honek A., MartinKova Z. \& Roy H.E. 2017: Species assemblages of ladybirds including the harlequin ladybird Harmonia axyridis: a comparison at large spatial scale in urban habitats. - BioControl 62: 409-421.

Wagner L.S., Fenoglio M.S. \& Salvo A. 2017: Alien species numerically dominate natural enemy communities in urban habitats: a preliminary study. - J. Entomol. Res. Soc. 19: 31-42.

With K.A., Pavuk D.M., Worchuck J.L., Oates R.K. \& Fisher J.L. 2002: Threshold effects of landscape structure on biological control in agroecosystems. - Ecol. Appl. 12: 52-65.

ZaKHAROV I.A. 2015: [Harmonia in Moscow.] — Priroda 2015: 92-93 [in Russian].

Received October 17, 2018; revised and accepted November 29, 2018 Published online December 17, 2018 